\title{
Pleiospermium sumatranum
}

Figure 3. Isotype from Sumatra. Fruiting twig. $1 / 4$ nat. size.

Figure 4. Type. Cross section of fruit. $\times 2$.

\section{Pleiospermium longisepalum}

Figure 5. Type from Banguey Island. Fruiting twig. 1/4 nat. size.

\section{Pleiospermium latialatum}

Figure 6. Type from North Borneo. Fruiting twig. $1 / 4$ nat. size.

Division of Plant Exploration and Introduction,

Bureau of Plant Industry, U. S. Department of Agriculture, Washington, D. C. 


\title{
ADDITIONAL NOTES ON HOUTTUYN'S BINOMIALS
}

\author{
E. D. MERrill
}

LAST YEAR I published a fairly comprehensive consideration of the numerous new binomials published by Houttuyn and by Christmann and Panzer between the years 1773 and 1788 , many of which had been overlooked by all botanists up to 1938.* The following brief notes for the most part include data that were not available at the time the article was published, or in one case, merely calls attention to the fact that I proposed a new binomial that had already been previously published by Thellung.

\section{GramineaE}

Chloris capensis (Houtt.) Thellung, Repert. Sp. Nov. 10:289. 1912; Merr. Jour. Arnold Arb. 19:317. 1938.

This is here mentioned merely to call attention to the fact that in 1912 Thellung made the above transfer, basing Chloris capensis Thellung on Andropogon capense Houtt. "Plant.-Syst. xii (1785), t. 93. f. 3," thus confusing the Christmann and Panzer "Pflanzensystem" with the original Houttuyn work, Nat. Hist. II. 13: Aanwyz. Plaat. [2.] $t .103$. f. 3. 1782, where Houttuyn's binomial first appears. Thellung's binomial is included in the fifth supplement to Index Kewensis but was overlooked by me, my attention having been called to it by Dr. J. Th. Henrard of the Rijks Herbarium, Leiden.

Stipa capillata Linn. Sp. Pl. ed. 2, 116. 1762.

Aristida avenacea Guettard ex Houtt. Nat. Hist. II. 13:375. 1782; Panzer, Pflanzensyst. 12: 512, 1785.

Stipa sp. Merr. Jour. Arnold Arb. 19: 321. 1938.

Copies of Guettard's two illustrations were sent to Dr. Schischkin, Director of the Principal Botanic Garden, Leningrad, who reports that they were examined by Dr. Rochewitz. The latter concluded that the plant illustrated by Guettard, on which Aristida avenacea Guettard, as published by Houttuyn, was based, represents nothing else than Stipa capillata Linn. which is still known in Ukrainia as "tirsa." Dr. Rochewitz

*Merrill, E. D. A critical consideration of Houttuyn's new genera and new species of plants, 1773-1783. Jour. Arnold Arb. 19:291-375. 1938. 
states that since the drawing was made from plants grown in the relatively humid climate of France, it is but natural that the leaves should be rather broad and the awns straight instead of geniculate. The same phenomenon may be observed in specimens of this species grown in Leningrad. Further allowance must be made for the individual imagination of the artist, who prepared Guettard's plates, whose knowledge of botany was evidently inadequate. This satisfactorily disposes of Aristida avenacea Guettard.

\section{IRIDACEAE}

Gladiolus lilaceus Houtt.; Merr. Jour. Arnold Arb. 19: 326. 1938.

Being unable to place this to my satisfaction an appeal was made to Dr. Compton, who states that Houttuyn's figure and description was shown to several botanists at Kirstenbosch, none of whom were able to identify it with certainty. He further states: "It may be a Homoglossum (formerly Antholyza) but the fact that the corolla is described as yellow removes it from any species known to us, although of course a colourvariety is not impossible."

\section{Proteaceae}

Leucadendron pedunculatum Meisn.; Merr. Jour. Arnold Arb. 19: 331. 1938, cum syn.

Protea linearis Houtt. was placed by me as a synonym of Leucadendron pedunculatum Meisn. with the statement that it was suspected, from Houttuyn's excellent figure, that the above species was represented. Dr. R. H. Compton, Director of the National Botanic Gardens at Kirstenbosch, confirms this, stating that Houttuyn's figure represents the male plant of Leucadendron tortum R. Br., as interpreted by Phillips \& Hutchinson, $=$ L. pedunculatum Meisn. N. E. Brown retains Leucadendron tortum (Thunb.) R. Br. for an entirely different species, the one described by Robert Brown in 1810 as Leucadendron fusciflorum $\mathrm{R}$. Br.

\section{Menispermaceae}

In accepting Tinospora glabra (Burm. f.) Merr. Jour. Arnold Arb. 19: 340. 1938 as the oldest valid name for a rather common Javan species, for which Diels accepted the invalid binomial Tinospora crispa (Linn.) Diels, Pflanzenr. 46(IV.94) : 142. f. 49. 1910, non Miers, I am now able to adjust the synonymy of the much misunderstood Tinospora crispa (Linn.) Miers. Dr. D. F. van Slooten courteously supplied me with authentic material of the form Boerlage called Tinospora Rumphii Boerl., 
at the same time calling my attention to the obscure publication of the new binomial Tinospora tuberculata Beumée. The following supplementary data are supplied:

Tinospora crispa (Linn.) Miers* in Hook. f. \& Th. Fl. Ind. 1: 183. 1855; Diels, Pflanzenr. 46(IV.94) : 142. 1910, pro parte.

Menispermun crispum Linn. Sp. P1. ed. 2, 1468, 1763.

Cocculus crispus DC. Syst. 1: 521. 1818.

Menispermum tuberculatum Lam. Encycl. 4: 96. 1797.

Menispermum verrucosum Flem. As. Res. 11: 171. 1807 (Cat. Ind. Med. Pl. 171) ; Roxb. F1. Ind. ed. 2, 3: 808. 1832.

Menispermum rimosum sensu Blanco, Fl. Filip. 810. 1837, non Spreng.

Tinospora Rumphii Boer1. Cat. Hort. Bogor. 116. 1901 ; Diels, Pflanzenreich 46(IV.94) : 135. 1910 ; Merr. Interpret. Rumph. Herb. Amb. 220. 1917, Sp. Blancoanae 145. 1918.

Tinospora Thorelii Gagnep. Bull. Soc. Bot. France 55: 46. 1908, Lecomte, Fl. Gén. Indo-Chine 1: 130. 1908.

Tinospora crispa Diels, Pflanzenr. 46(IV.94): 142. 1910, pro parte.

Tinospora tuberculata Beumée in Heyne, Nuttige Pl. Nederl. Ind. ed. 2, 1: 619. 1927.

Funis felleus Rumph. Herb. Amb. 5: 82. t. 44. f. 1. 1747.

This is a case of consistent modern misinterpretations of a Linnaean binomial, for no matter what material Miers may have had before him, Tinospora crispa Miers must be interpreted by the Linnaean binomial on which it was based, Menispermum crispum Linn. This Linnaean binomial was based wholly on "Funis quadrangularis, Rumph. amb. 5, p. 83. t. 44. f. 1.", which, as I noted, this Journal 19: 341. 1938, involved some confusion, on the part of Linnaeus, between two entirely different plants, Funis quadrangularis Rumph., fig. 2, and Funis felleus Rumph, fig. 1, both illustrated on the same plate. The former is Cissus quadrangularis Linn., and the latter is the plant with which we are concerned; Linnaeus' reference is to fig. 1 . There is no possible doubt as to what he actually intended by his Menispermum crispum, for he cites the menispermaceous figure, not the vitaceous one. And yet, Diels, in his confused synonymy of Tinospora crispa (Linn.) Diels, cites Rumphius' distinctly good illustration of Funis felleus, the form with which we are concerned, i.e., the one with broadly ovate, prominently cordate leaves and very verrucose stems, in his synonymy of what is an entirely different species. The latter as illustrated and described by him, fig. 49, D-O, is a form with narrower oblong leaves which are only subtruncate or slightly cordate, and smooth stems. This is clearly the one described by Burman f. as

\footnotetext{
*In many references this binomial is credited to Miers, Ann. Mag. Nat. Hist. II. $7: 38.1851$; it does not there appear.
} 
Menispermum glabrum Burm. f. Fl. Ind. 216. $1768=$ Tinospora glabra (Burm. f.) Merr. Jour. Arnold Arb. 19: 340. 1938. Most of the synonyms cited by Diels belong with Tinospora crispa (Linn.) Miers, the form described in detail by Diels as Tinospora Rumphii Boerl. Beumée, in replacing Tinospora Rumphii Diels by the older Tinospora tuberculata (Lam.) Beumée, overlooked the fact that Menispermum tuberculatum Lam. was essentially only a new name for Menispermum crispum Linn., and by citing Tinosporum crispum Linn., pro parte, failed to realize that Linnaeus had no actual specimen, and that the sole basis of the Linnaean binomial was the Rumphian illustration. There is no possible "pro parte" unless we wish to interpret Linnaeus' inadvertent confusion of Funis quadrangularis Rumph. (Cissus quadrangularis Linn.) and Funis felleus Rumph. (Menispermum crispum Linn.) as noted above. There is no specimen in the Linnaean herbarium, Linnaeus' "Habitat in Bengala" having been taken from Rumphius' statement under Funis quadrangularis "Ex Bengala in Bataviam translatus erit hic funis -." ; this appertains to Cissus quadrangularis Linn., not to Menispermum crispum Linn.

Tinospora crispa (Linn.) Miers (not Tinospora crispa Diels) is widely distributed in southern Asia and in Malaysia, and is certainly an introduced plant in the Malay Archipelago as it is in the Philippines; Rumphius notes that his Funis felleus had been introduced into Amboina in about 1690 but does not indicate its source. It owed its wide distribution to its highly reputed medicinal qualities, the juice being very bitter. It is excellently represented by Merrill, Species Blancoanae 903, stems and staminate flowers, March, 1915, and 1003, leaf specimen from the same plant, October, 1916, this plant being leafless at the time of anthesis. These specimens conform entirely to Tinospora Rumphii Boerl, having but three small petals instead of the normal six petals that are found in the other known species of the genus. The fresh branches are much more prominently verrucose than are the dried ones, the Rumphian illustration having been drawn from a fresh specimen.

Dr. Beumée apparently realized the confusion caused by Diels' erroneous treatment of Tinospora crispa, and attempted to establish valid names for the two species confused in the latter's consideration, but failed to carry through the interpretation of Menispermum crispum Linn. to its logical conclusion. In publishing Tinospora tuberculata (Lam.) Beumée, for what proves to be the true Tinospora crispa (Linn.) Miers, he also attempted to establish a valid binomial for the other part of what Diels included in Tinospora crispa (Linn.) Diels in Tinospora coriacea (Blume) Beumée. This falls as a synonym of Tinospora glabra (Burm. f.) Merr.: 


\section{$2 \mathrm{BHL}$ Biodiversity Heritage Library}

Merrill, Elmer D. 1939. "Additional Notes on Houttuyn's Binomials." Journal of the Arnold Arboretum 20(2), 264-268. https://doi.org/10.5962/p.185416.

View This Item Online: https://www.biodiversitylibrary.org/item/33596

DOI: https://doi.org/10.5962/p.185416

Permalink: https://www.biodiversitylibrary.org/partpdf/185416

\section{Holding Institution}

Missouri Botanical Garden, Peter H. Raven Library

\section{Sponsored by}

Missouri Botanical Garden

\section{Copyright \& Reuse}

Copyright Status: In copyright. Digitized with the permission of the rights holder.

Rights Holder: Arnold Arboretum of Harvard University

License: http://creativecommons.org/licenses/by-nc-sa/3.0/

Rights: https://biodiversitylibrary.org/permissions

This document was created from content at the Biodiversity Heritage Library, the world's largest open access digital library for biodiversity literature and archives. Visit BHL at https://www.biodiversitylibrary.org. 